\title{
Perumusan Faktor - Faktor Perubahan Penggunaan Lahan Akibat Pembangunan Jalan Tol Waru - Juanda di Kelurahan Tambakoso Kabupaten Sidoarjo
}

\author{
Artha Agung Alank Sigit Permadi Putra dan Putu Rudy Satiawan \\ Departemen Perencanaan Wilayah dan Kota, Fakultas Arsitektur, Desain, dan Perencanaan \\ Institut Teknologi Sepuluh Nopember (ITS) \\ E-mail: puturudy@gmail.com
}

\begin{abstract}
Abstrak-Perkembangan di Kelurahan Tambakoso merupakan salah satu upaya Kabupaten Sidoarjo untuk melakukan pemerataan pembangunan di Jawa Timur. Upaya pemerataan pembangunan yang dilakukan Kabupaten Sidoarjo khususnya di Kelurahan Tambakoso adalah dengan membangun akses jalan tol Waru-Juanda. Gerbang Tol Tambak Sumur 1 dan 2 yang berdekatan dengan Kelurahan Tambakoso meningkatkan nilai lahan di sekitar koridor jalan tersebut karena adanya peningkatan aksesibilitas yang ada. Peningkatan nilai lokasi ini kemudian menyebabkan perubahan penggunaan lahan. Perumusan faktor-faktor penyebab perubahan penggunaan lahan Penelitian ini bertujuan untuk merumuskan faktor-faktor perubahan penggunaan lahan akibat pembangunan jalan tol Waru - Juanda di kelurahan tambakoso. Untuk mencapai tujuan tersebut, dilakukan dua tahapan yaitu mengidentifikasi karakteristik perubahan penggunaan lahan berdasarkan jenisjenis perubahan lahan dengan menggunakan analisis deskriptif serta perumusan faktor-faktor perubahan lahan sesuai dengan karakteristik perubahan penggunaan lahan sebelum dan sesudah pembangunan jalan tol Waru - Juanda dengan menggunakan analisis delphi. Berdasarkan hasil analisis Faktor - Faktor yang berpengaruh terhadap perubahan penggunaan lahan akibat pembangunan jalan tol Waru - Juanda periode 2004 - 2009 adalah Harga lahan (NJOP), Aksesbilitas, Kebijakan, Kebutuhan penduduk terhadap lahan. Faktor Faktor yang berpengaruh terhadap perubahan penggunaan lahan akibat pembangunan jalan tol Waru - Juanda periode 2009 - 2017 adalah Harga lahan (NJOP), Aksesbilitas, Produktivitas lahan, Kebijakan, Kebutuhan penduduk terhadap lahan.
\end{abstract}

Kata Kunci-Perubahan Penggunaan Lahan, Jalan Tol Waru Juanda, Kelurahan Tambakoso.

\section{PENDAHULUAN}

A LIH fungsi lahan dalam arti perubahan penggunaan lahan, pada dasarnya tidak dapat dihindarkan dalam pelaksanaan pembangunan. Pertumbuhan penduduk yang pesat serta bertambahnya tuntutan kebutuhan masyarakat akan lahan, seringkali mengakibatkan benturan kepentingan atas penggunaan lahan serta terjadinya ketidaksesuaian antara penggunaan lahan dengan rencana peruntukannya. Sedangkan lahan itu sendiri bersifat terbatas dan tidak bisa ditambah kecuali dengan kegiatan reklamasi. Keterbatasan lahan di perkotaan juga menyebabkan kota berkembang secara fisik ke arah pinggiran kota

Adapun bentuk pengelolaan tanah yang dilakukan pemerintah meliputi perencanaan, jaringan infrastruktur, dan fungsi pengaturan untuk tujuan melakukan perluasan kota dalam memberikan kerangka fisik dan hukum setiap proyek pembangunan yang dilakukan oleh pihak swasta maupun masyarakat menyatakan bahwa perubahan lahan terutama yang terjadi di wilayah perkotaan disebabkan adanya pembangunan jalan kolektor primer dalam skalabesar di wilayah pinggiran kota dimana pembangunannya akan mengkonsumsi lahan di wilayah tersebut dan akan terjadi pembangunan.

Pembangunan selalu identik dengan wilayah perkotaan, bahkan tiap tahun angka pembangunan di hampir seluruh wilayah perkotaan di Indonesia selalu mengalami peningkatan. Tingginya permintaan lahan terbangun tidak lain dipengaruhi oleh semakin tingginya tingkat pertumbuhan penduduk perkotaan baik secara alami (fertilitas dan mortalitas), maupun migrasi. Jenis pembangunan yang dilakukan cukup beragam, seperti pembangunan kawasan permukiman, perdagangan dan jasa, perindustrian, dan lainlain. Pembangunan yang diterapkan terhadap suatu kawasan harus berdasarkan potensi dan kondisi yang dimiliki suatu wilayah, harus sesuai dengan kapabilitas, kesesuaian dan daya dukung lahan, maka diharapkan hasil produksi dan tingkat produktivitas akan lebih tinggi, yang berarti tingkat keberhasilan yang dicapai adalah optimum atau mencapai tingkat optimalitas[1].

Perubahan penggunaan lahan tersebut juga bukannya tanpa ada sebab, terdapat empat faktor utama yang menyebabkan terjadinya perubahan penggunaan lahan yaitu: Perluasan batas kota, Peremajaan pusat kota, Perluasan jaringan infrastruktur khususnya jaringan transportasi, Tumbuh dan hilangnya pemusatan aktivitas tertentu. Pengertian perubahan penggunaan lahan secara umum adalah transformasi dalam mengalokasikan sumberdaya lahan dari suatu pengguna ke pengguna lainnya. Pola pemekaran atau ekspansi kota mengikuti jalur transportasi menurut, antara lain sebagai berikut : Perluasan akan mengikuti jalur jalan transportasi ke daerah-daerah perbatasan kota. Daerah-daerah hinterland di luar kota semakin lama semakin berkembang dan akhirnya menggabung pada kota yang lebih besar. Menggabungkan kota inti dengan kota-kota kecil yang berada di luar kota inti atau disebut dengan konurbasi.

Pada kesempatan kali ini, wilayah yang akan dibahas yaitu Kecamatan Waru khususnya yang terletak di Kelurahan Tambakoso. Aktivitas pembangunan yang terjadi di Kelurahan Tambakoso adalah perubahan guna lahan dari lahan hijau menjadi lahan terbangun. Jenis aktivitas yang berkembang di Kelurahan Tambakoso adalah permukiman serta perdagangan dan jasa. 
Perkembangan di Kelurahan Tambakoso merupakan salah satu upaya Kabupaten Sidoarjo untuk melakukan pemerataan pembangunan di Jawa Timur. Upaya pemerataan pembangunan yang dilakukan Kabupaten Sidoarjo khususnya di Kelurahan Tambakoso adalah dengan membangun akses jalan tol Waru-Juanda[2].

Jalan Tol Waru-Juanda adalah sebuah Jalan Tol sepanjang 12,8 kilometer yang menghubungkan antara Bundaran Waru, Sidoarjo selatan Kota Surabaya dengan Bandar Udara Internasional Juanda. Jalan tol ini diresmikan penggunaannya oleh Presiden Susilo Bambang Yudhoyono pada tahun 2008. Jalan Tol sepanjang $12 \mathrm{~km}$ ini melintasi Surabaya dan Sidoarjo dan memiliki gerbang tol di 6 lokasi yaitu : Gerbang Tol Menanggal, Gerbang Tol Berbek 1, Gerbang Tol Berbek 2, Gerbang Tol Tambaksumur 1, Gerbang Tol Tambaksumur 2, Gerbang Tol Juanda.

Pembangunan Jalan Tol berlangsung sejak 1996 - 2008 pengelola oleh PT.Citra Margatama Surabaya, Tbk. Jalan Tol Waru-Bandara Juanda ini diharapkan memperlancar akses dari dan menuju Bandara Juanda serta mengatasi kemacetan di sekitar Bundaran Waru, Jl. Jemur Andayani, Jl. Brigjen Katamso dan Jl. Raya Wadungasri yang selama ini merupakan simpul-simpul kemacetan di kawasan Surabaya Selatan dan Sidoarjo. Jalan tol ini akan terintegrasi dengan Jalan Tol Surabaya-Mojokerto dan Tol Aloha-WonokromoPerak.

Adanya aksesibilitas jalan tol juga turut menjadi magnet bagi masyarakat luar Kelurahan Tambakoso untuk berinvestasi maupun untuk bermukim. Hal ini terbukti dengan masuknya developer perumahan menengah kebawah hingga menengah keatas untuk melakukan pembangunan perumahan disana. Seiring dengan bertambahnya kawasan perumahan disana juga turut berkembang berbagai aktivitas penunjang seperti perdagangan dan jasa. Berkembangnya aktivitas perdagangan dan jasa ditandai dengan meningkatnya tingkat keberagaman jenis perdagangan dan jasa di Kelurahan Tambakoso.

Berdasarkan hal tersebut maka penulis membuat penelitian “ Perumusan Faktor - Faktor Perubahan Penggunaan Lahan Akibat Pembangunan Jalan Tol Waru - Juanda di Kelurahan Tambakoso“ sebagai pengembangan ilmu perencanaan wilayah dan kota bidang tata guna lahan terhadap perubahan penggunaan lahan.

\section{METODE PENELITIAN}

\section{A. Jenis dan Pendekatan Penelitian}

Pendekatan yang digunakan dalam penelitian ini adalah pendekatan rasionalistik. Jenis penelitian dalam penelitian ini adalah deskripti kuantitatif dan kualitatif.

\section{B. Variabel Penelitian}

Variabel penelitian yang digunakan untuk mengidentifikasi karakteristik perubahan penggunaan lahan akibat pembangunan jalan tol Waru - Juanda di kelurahan tambakoso antara lain jenis perubahan penggunaan lahan dan luas perubahan penggunaan lahan.

Variabel penelitian yang digunakan untuk analisis faktor faktor perubahan penggunaan lahan akibat pembangunan jalan tol Waru - Juanda di kelurahan tambakoso antar lain kebutuhan penduduk terhadap lahan, produktivitas lahan, harga lahan, Rencana Dasar Tata Ruang, Ketersediaan Sarana dan Prasarana, Aksesbilitas.
C. Mengidentifikasi Karakteristik Perubahan Penggunaan Lahan Akibat Pembangunan Jalan Tol Waru - Juanda di Kelurahan Tambakoso Kabupaten Sidoarjo

Analisis untuk merumuskan karakteristik perubahan penggunaan lahan adalah dengan menggunakan analisis deskriptif kuantitatif yang didapatkan melalui analisi overlay pada Sistem Informasi Geografis untuk mengetahui luas perubahan lahan berdasarkan variabel yang dibutuhkan. Untuk mendukung analisis ini maka analisis disajikan dalam bentuk tabel untuk menggambarkan perubahan penggunaan lahan yang terjadi. Variabel yang digunakan untuk mengetahui karakteristik perubahan penggunaan lahan yang terjadi adalah jenis-jenis perubahan lahan, luas lahan. Kemudian data tersebut di proses dengan data berupa luas perubahan lahan dan perubahan lahan yang terjadi pada periode tahun 2004, 2009, dan 2017.

D. Menganalisis Faktor - Faktor Perubahan Penggunaan Lahan Akibat Pembangunan Jalan Tol Waru - Juanda di Kelurahan Tambakoso Kabupaten Sidoarjo

Analisis faktor-faktor penyebab perubahan penggunaan lahan dilakukan dengan menggunakan teknik analisis Delphi pada periode sebelum pembangunan jalan tol ( 2004 - 2009) dan setelah pembangunan jalan tol ( 2009 - 2017 ). Teknik analisis delphi merupakan prosedur peramalan pendapat untuk memperoleh, menukar, dan membuat opini tentang peristiwa di masa depan dengan mencari konsensus diantara kelompok pakar yang homogen. Analisis delphi dilakukan dengan melakukan wawancara kepada responden-responden. Adapun responden yang digunakan dalam analisis Delphi telah ditetapkan berdasarkan purposive sampling.

Langkah-langkah yang ditempuh untuk melakukan analisis delphi dalam penelitian ini adalah:

1. Merumuskan masalah penelitian dan variabel penelitian;

2. Menentukan pelaku-pelaku kunci atau pakar terhadap aspek yang diteliti (berdasarkan analisis stakeholder);

3. Merumuskan kuisioner putaran i dengan menentukan faktor-faktor mana saja yang diajukan dalam kuisioner;

4. Melakukan analisis hasil putaran pertama dengan cara mengumpulkan dan memverifikasi hasil pendapat pakar, menginterpretasi kecenderungan pendapat pakar, mendefinisikan faktor berdasarkan hasil kuisioner, mengeksplorasi faktor penyebab, dan mengeliminasi pertanyaan-pertanyaan yang tidak diperlukan lagi untuk putaran berikutnya;

5. Menyusun pertanyaan untuk kuisioner putaran ke ii, dan seterusnya.

Dalam penelitian ini dilakukan iterasi dalam beberapa putaran hingga memenuhi kebutuhan penelitian,yaitu adanya konsensus mengenai faktor penyebab perubahan penggunaan lahan akibat pembangunan jalan tol Waru - Juanda.

E. Perumusan Faktor - Faktor Perubahan Penggunaan Lahan Akibat Pembangunan Jalan Tol Waru - Juanda di Kelurahan Tambakoso Kabupaten Sidoarjo

Dalam melakukan metode analisis ini dilakukan dengan cara mengkomparasikan antara hasil identifikasi karakteristik perubahan penggunaan lahan dengan analisis faktor - faktor perubahan penggunaan lahan. 


\section{HASIL DAN DISKUSI}

A. Identifikasi Karakteristik Perubahan Penggunaan LAhan Akibat Pembangunan Jalan Tol Waru - Juanda di Kelurahan Tambakoso Kabupaten Sidoarjo

Adapun ruang lingkup wilayah pada penelitian ini terletak di Kecamatan Waru Kabupaten Sidoarjo yaitu Kelurahan Tambakoso sebagai lokasi perubahan penggunaan lahan akibat pembangunan jalan tol Waru - Juanda. Wilayah penelitian ini berbatasan dengan wilayah administratif sebagai berikut.

- Sebelah Utara : Kel. Gunung Anyar Tambak

Kec. Gunung Anyar

- Sebelah Timur : Kel. Tambaksumur Kec. Waru

- Sebelah Selatan : Kel. Banjar Kemuning Kec. Sedati

- Sebelah Barat : Kel. Segoro Tambak Kec. Sedati

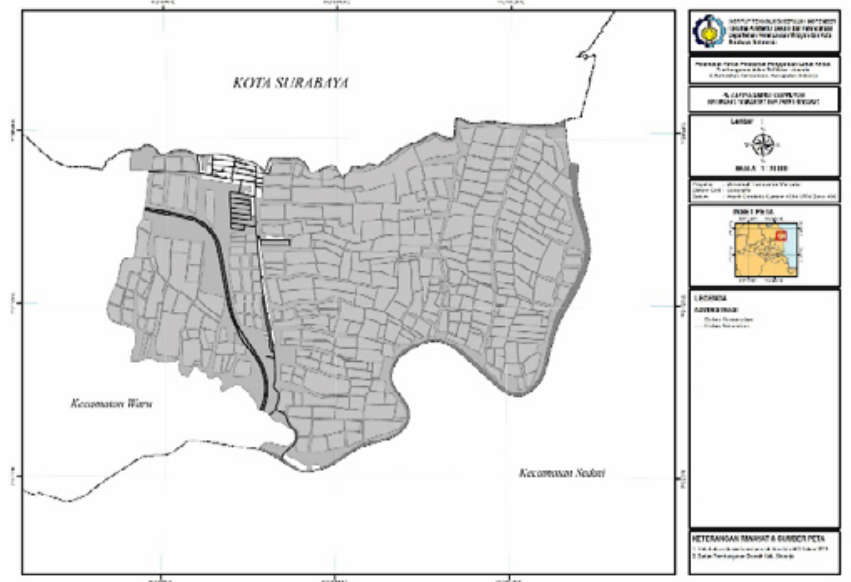

Gambar 1. Peta Batas Administrasi Wilayah Studi

Pada Periode ( 2004 - 2009 ) sebelum pembangunan jalan tol perubahan lahan terjadi pada lahan tambak menjadi permukiman, perdagangan dan jasa serta fasilitas umum. Perubahan lahan menjadi perumahan ini terdiri dari rumah tinggal yang terdapat pada perkampungan. Sedangkan perubahan penggunaan lahan menjadi perdagangan dan jasa berupa toko dan Warung. Selain itu terdapat pula perubahan penggunaan lahan dari ladang menjadi RTH dan Permukiman.

Tabel 1.

Perubahan Penggunaan Lahan Tahun 2004 - 2009

\begin{tabular}{ccc}
\hline \hline Penggunaan Lahan & Menjadi & Luas \\
\hline Tambak & Perdagangan dan Jasa & 0,02 \\
& Permukiman & 2,02 \\
& Fasilitas Umum & 0,00086 \\
Ladang & RTH & 16,02 \\
& Permukiman & 0,004 \\
\hline \hline
\end{tabular}

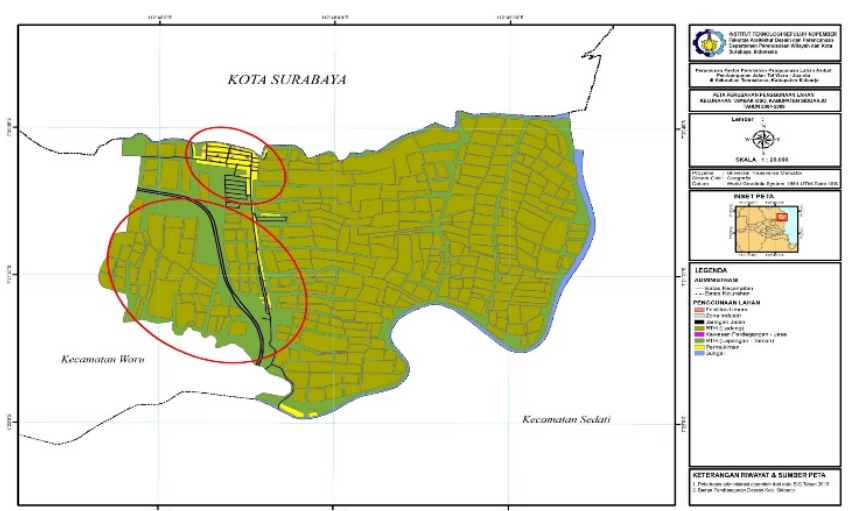

Gambar 2. Peta Perubahan Penggunaan Lahan Kelurahan Tambakoso Tahun $2004-2009$
Pada Periode ( 2009 - 2017 ) sesudah pembangunan jalan tol yang telah resmi disahkan pada tahun 2008 desa tambakoso berdekatan dengan gerbang tol Tambaksumur 1 dan 2 hal ini memberikan kemudahan aksesbilitas sehingga meningkatkan jumlah pengguna jalan. Perubahan lahan terjadi pada lahan RTH menjadi industry, permukiman, perdagangan dan jasa serta fasilitas umum. Perubahan lahan menjadi permukiman ini terdiri dari rumah tinggal yang terdapat pada perkampungan dan pembangunan apartemen, perubahan penggunaan lahan menjadi perdagangan dan jasa berupa pembangunan ruko, perubahan penggunaan lahan menjadi Industri berupa pembangunan industry beton oleh PT. Varia Beton, perubahan penggunaan lahan menjadi Fasilitas Umum berupa pembangunan Kantor Desa dan masjid.

Tabel 2

Perubahan Penggunaan Lahan Tahun 2009 - 2017

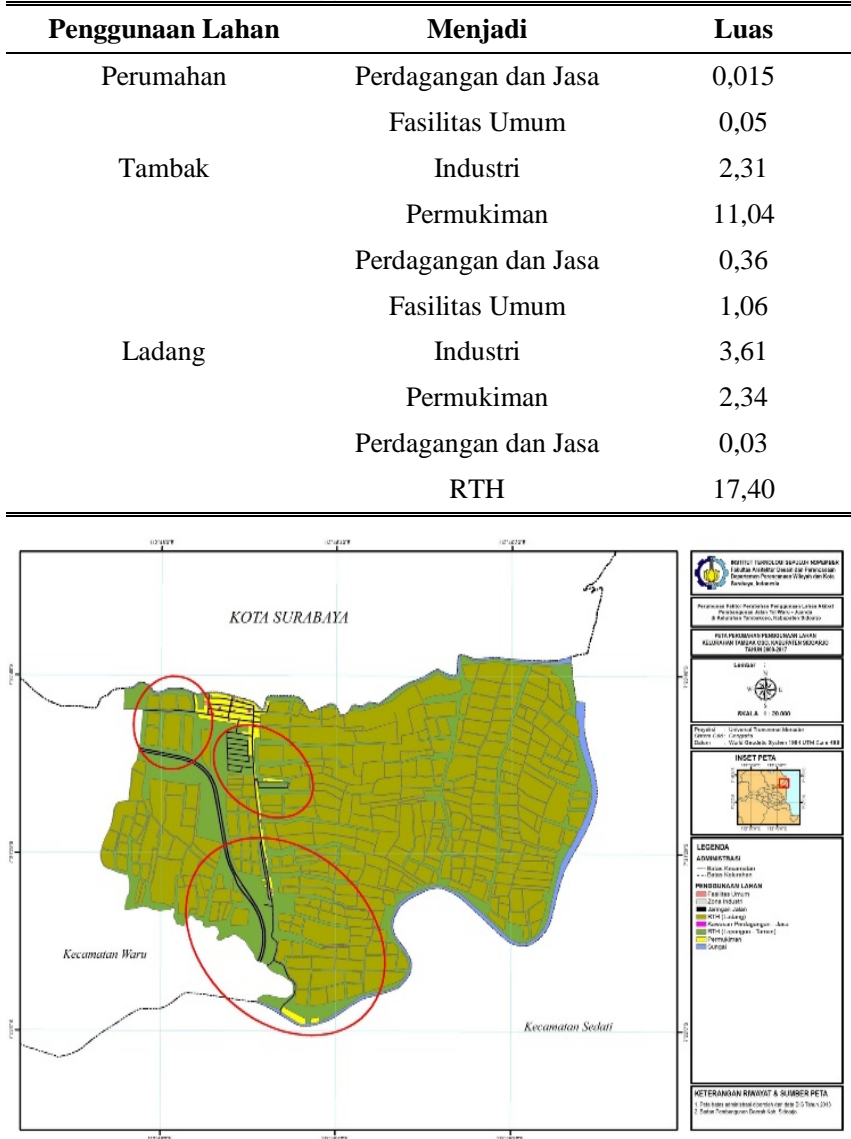

Gambar 3. Peta Perubahan Penggunaan Lahan Kelurahan Tambakoso Tahun 2009 - 2017

B. Analisis Faktor - Faktor Perubahan Penggunaan Lahan Sebelum Pembangunan Jalan Tol Waru - Juanda di Kelurahan Tambakoso Kabupaten Sidoarjo Periode 2004 2009

Analisis ini dilakukan menggunakan penyebaran kuesioner melalui analisis Delphi untuk mengidentifikasi faktor penyebab perubahan penggunaan lahan sebelum pembangunan jalan tol Waru - Juanda di Kelurahan Tambakoso periode 2004 - 2009 . Analisis Delphi ini dilakukan melalui 2 tahap pencarian faktor serta perumusan faktor.

Tahap pertama merupakan tahap pengujian Validitas Faktor Penyebab Perubahan Penggunaan Lahan sebelum Pembangunan Jalan Tol Waru - Juanda di Kelurahan Tambakoso periode 2004 - 2009 yang dilakukan dengan mengkaji variabel penelitian dengan kondisi eksisting 
wilayah penelitian. Tahap pertama dilakukan dengan analisis deskriptif yang berupa deskripsi:

Tabel 3

Analisis Delphi Tahap 1

\begin{tabular}{clllll}
\hline \hline Faktor & R1 & R2 & R3 & R4 & R5 \\
\hline Harga Lahan( NJOP ) & B & B & B & B & B \\
Aksebilitas & B & B & B & B & B \\
Produktivitas Lahan & B & B & B & TB & B \\
Ketersediaan Sarana dan Prasarana & TB & B & B & TB & B \\
Kebijakan & B & B & B & TB & B \\
Kebutuhan Penduduk Terhadap Lahan & B & B & B & B & B \\
\hline \hline
\end{tabular}

\section{Keterangan}

B : Berpengaruh

TB : Tidak Berpengaruh

R1 : Bappeda Kab Sidoarjo

R2 : PUPR Kab Sidoarjo

R3 : Direktur PT.SIPOA

R4 : Pakar Akademisi

R5 : Tokoh Masyarakat

\section{1) Faktor Harga Lahan}

Kelima responden sependapat bahwa faktor harga lahan berpengaruh terhadap perubahan lahan. Menurut para responden, harga lahan yang rendah dapat mempengaruhi perubahan lahan karena harga lahan yang rendah dapat terjangkau oleh pembeli lahan. Berdasarkan penjelasan tersebut maka dapat disimpulkan bahwa harga lahan merupakan faktor yang berpengaruh terhadap perubahan lahan .

\section{2) Faktor Aksesibilitas}

Kelima responden sependapat bahwa faktor aksesibilitas berpengaruh terhadap perubahan lahan. Responden 1,4 dan 5 berpendapat bahwa akses yang baik dapat mempengaruhi perubahan lahan di sekitarnya sehingga dapat berpengaruh terhadap perubahan lahan yang terjadi, adanya gerbang tol tambak sumur 1 dan 2 akan menimbulkan tingginya aktivitas yang terjadi disekitar jalan tersebut sehingga akan berpengaruh terhadap perubahan lahan di sekitar jalan tersebut, sedangkan responden 2 dan 3 berpendapat bahwa aksesibilitas merupakan salah satu penyebab terjadinya perubahan lahan karena akses yang baik dapat menarik minat investor maupun masyarakat untuk membangun perdagangan dan jasa di sekitar akses tersebut. Berdasarkan penjelasan tersebut maka dapat disimpulkan bahwa faktor aksesibilitas berpengaruh terhadap perubahan lahan.

\section{3) Faktor Produktivitas Lahan}

Responden 1, 2, 3 dan 5 sependapat bahwa produktivitas lahan berpengaruh terhadap perubahan lahan. Produktivitas lahan yang dimaksud responden adalah kegunaan dari rumah tempat tinggal sehingga pemilik rumah tidak akan menjual rumahnya untuk di alih fungsikan. Sedangkan menurut pendapat responden 4 bahwa produktivitas lahan bukan faktor yang berpengaruh terhadap perubahan lahan. Produktivitas lahan bukan alasan utama terjadinya perubahan lahan, bukan untuk lahan permukiman. Berdasarkan penjelasan tersebut maka dapat disimpulkan bahwa faktor produktivitas lahan belum tentu berpengaruh terhadap perubahan lahan.

\section{4) Faktor Ketersediaan Sarana dan Prasarana}

Responden 2, 3, 5 berpendapat bahwa faktor ketersediaan sarana prasana berpengaruh terhadap perubahan lahan. Ketersediaan sarana prasarana dinilai mampu membuat investor tertarik untuk melakukan pembangunan di sekitar kawasan tersebut. Hal ini didasari karena kelengkapan sarana dan prasarana ini mempu mengakomodasi kebutuhan akan suatu kawasan. Sedangkan pendapat responden 1, 4 berpendapat bahwa faktor sarana dan prasarana bukan faktor yang berpengaruh terhadap perubahan lahan karena sarana prasarana bukan satu satunya faktor yang mempengaruhi perubahan lahan, pendapat responden 1,4 bahwa faktor seperti aksesibilitas yang sangat mempengaruhi perubahan lahan.

\section{5) Faktor Kebijakan}

Responden 1, 2, 3 dan 5 sependapat bahwa faktor kebijakan berpengaruh terhadap perubahan lahan. Menurut keempat responden, suatu kebijakan dapat menentukan arah pembangunan sehingga kebijakan akan selalu menjadi salah satu faktor yang mempengaruhi perubahan lahan yang terjadi. Sedangkan menurut responden 4 berpendapat bahwa kebijakan bukan faktor yang berpengaruh terhadap perubahan lahan. Menurut responden kebijakan yang ada masih belum dapat optimal karena rendahnya pengawasan dari pihak pihak yang berwenang, hal itu menyebabkan perubahan lahan menjadi tidak terkendali. Berdasarkan penjelasan tersebut maka dapat disimpulkan bahwa faktor kebijakan belum tentu berpengaruh terhadap perubahan lahan.

\section{6) Faktor Kebutuhan Penduduk Terhadap Lahan}

Kelima responden sependapat bahwa faktor kebutuhan penduduk terhadap lahan berpengaruh terhadap perubahan lahan. Perubahan lahan disebabkan oleh tingginya aktivitas ekonomi akibat dibangunnya sehingga maraknya pembangunan perdagangan dan jasa disekitar kawasan, oleh karena itu kebutuhan penduduk terhadap lahan merupakan faktor yang mempengaruhi perubahan lahan. Berdasarkan penjelasan tersebut maka dapat disimpulkan bahwa faktor kebutuhan penduduk terhadap lahan berpengaruh terhadap perubahan lahan.

Berdasarkan penjelasan sebelumnya, masih terdapat beberapa responden yang menyatakan ketidaksetujuan atas fakto-faktor yang ada di masing-masing jenis perubahannya. Tetapi dalam iterasi tahap 1, responden berpendapat bahwa faktor yang diberikan sudah mencukupi sehingga tidak perlu penambahan faktor. Untuk mendapatkan jawaban atas berpengaruh atau tidaknya faktor dalam masing-masing jenis perubahan lahan dilakukan wawancara Delphi tahap II kepada seluruh responden dengan menanyakan beberapa faktor diatas. Untuk lebih jelasnya dapat dilihat pada Lampiran. Berikut

Tabel 4.

Tabel Analisis Delphi Tahap 2

\begin{tabular}{llllll}
\hline \hline \multicolumn{1}{c}{ Faktor } & R1 & R2 & R3 & R4 & R5 \\
\hline Produktivitas Lahan & TB & TB & TB & TB & TB \\
Ketersediaan Sarana dan Prasarana & TB & TB & TB & TB & TB \\
Kebijakan & B & B & B & B & B \\
\hline \hline Keterangan: & & & & & \\
B : Berpengaruh & & & & & \\
TB : Tidak Berpengaruh & & & & & \\
R1 : Bappeda Kab Sidoarjo & & & & & \\
R2 : PUPR Kab Sidoarjo & & & & & \\
R3 : Direktur PT.SIPOA & & & & & \\
R4 : Pakar Akademisi & & & & & \\
R5 : Tokoh Masyarakat & & & & & \\
7) Faktor Produktivitas Lahan & & & & &
\end{tabular}

Dalam iterasi ke II, kelima responden sependapat bahwa faktor produktivitas lahan tidak berpengaruh terhadap perubahan lahan. Ke empat responden (responden 1,2,3,dan 5) mengatakan faktor produktivitas lahan tidak berpengaruh pada wawancara Delphi tahap II dengan alasan produktivitas lahan yang tinggi maupun rendah bukanlah penyebab dari perubahan lahan. Berdasarkan penjelasan di atas, 
Produktivitas lahan tidak menjadi faktor penyebab perubahan lahan.

\section{8) Faktor Ketersediaan Saran Prasarana}

Dalam iterasi ke II, kelima responden sependapat bahwa faktor kesediaan sarana prasarana tidak berpengaruh terhadap perubahan lahan, responden yang pada awalnya menyatakan berpengaruh (responden 2, 3, 5) telah menyatakan tidak berpengaruh pada wawancara Delphi tahap II dengan alasan ketersediaan sarana prasarana yang ada di sekitar kawasan sudah mencukupi kebutuhan penduduk atau kebutuhan permukiman sehingga ketersediaan sarana prasarana bukanlah pengaruh dari perubahan lahan.

Sementara 1, dan 4 menyatakan pendapat yang sama seperti yang telah diungkapkan pada iterasi tahap I. Berdasarkan penjelasan tersebut maka selanjutnya dapat disimpulkan bahwa Faktor ketersediaan sarana prasarana tidak berpengaruh terhadap perubahan lahan.

9) Faktor Kebijakan

Dalam iterasi ke II, kelima responden sependapat bahwa faktor kebijakan berpengaruh terhadap perubahan lahan. Dua responden yang pada awalnya menyatakan tidak berpengaruh (responden 4) telah menyatakan berpengaruh pada wawancara Delphi tahap II dengan alasan meskipun kebijakan kurang baik, faktor tersebut tetap berpengaruh dalam perubahan lahan.

Sementara responden 1, 2, 3 dan 5 menyatakan pendapat yang sama seperti yang telah diungkapkan pada iterasi tahap I. Berdasarkan penjelasan tersebut maka selanjutnya dapat disimpulkan bahwa Faktor kebijakan berpengaruh terhadap perubahan lahan.

C. Analisis Faktor - Faktor Perubahan Penggunaan Lahan Setelah Pembangunan Jalan Tol Waru - Juanda di Kelurahan Tambakoso Kabupaten Sidoarjo Periode 2009 2017

Analisis ini dilakukan menggunakan penyebaran kuesioner melalui analisis Delphi untuk mengidentifikasi faktor penyebab perubahan penggunaan lahan akibat pembangunan jalan tol Waru - Juanda di Kelurahan Tambakoso. Analisis Delphi ini dilakukan melalui 2 tahap pencarian faktor serta perumusan faktor.

Tahap pertama merupakan tahap pengujian Validitas Faktor Penyebab Perubahan Penggunaan Lahan Akibat Pembangunan Jalan Tol Waru - Juanda di Kelurahan Tambakoso yang dilakukan dengan mengkaji variabel penelitian dengan kondisi eksisting wilayah penelitian. Tahap pertama dilakukan dengan analisis deskriptif yang berupa deskripsi:

Tabel 5.

Tabel Analisis Delphi Tahap 1

\begin{tabular}{llllll}
\multicolumn{1}{c}{ Tabel Analisis Delphi Tahap 1 } & & & \\
\hline \hline & R1 & R2 & R3 & R4 & R5 \\
\hline Harga Lahan ( NJOP ) & B & B & B & TB & B \\
Aksebilitas & B & B & B & B & B \\
Produktivitas Lahan & B & B & B & TB & B \\
Ketersediaan Sarana dan Prasarana & TB & B & B & TB & B \\
Kebijakan & B & B & B & B & B \\
Kebutuhan Penduduk Terhadap Lahan & B & B & B & B & B \\
\hline \hline
\end{tabular}

Keterangan:

B : Berpengaruh

TB : Tidak Berpengaruh

R1 : Bappeda Kab Sidoarjo

R2 : PUPR Kab Sidoarjo

R3 : Direktur PT.SIPOA

R4 : Pakar Akademisi

R5 : Tokoh Masyarakat

\section{1) Faktor Harga Lahan}

Responden 1,2,3 dan 5 sependapat bahwa faktor harga lahan berpengaruh terhadap perubahan penggunaan lahan akibat pembangunan jalan tol Waru - Juanda . Menurut para responden, harga lahan dapat mempengaruhi perubahan lahan, harga lahan yang rendah dapat terjangkau oleh masyarakat yang ekonomi menengah kebawah. Namun R4 berpendapat bahwa harga lahan tidak berpengaruh terhadap perubahan penggunaan lahan karena harga lahan melihat kondisi eksisting lokasi sehingga bukan menjadi faktor utama perubahan lahan. Berdasarkan penjelasan tersebut maka dapat disimpulkan bahwa faktor harga lahan belum tentu berpengaruh terhadap perubahan lahan.

\section{2) Faktor Aksesibilitas}

Kelima responden sependapat bahwa faktor aksesibilitas berpengaruh terhadap perubahan lahan. Responden 2,3 dan 5 berpendapat bahwa akses yang baik dan lebar dapat memepngaruhi perubahan lahan di sekitarnya sehingga dapat berpengaruh terhadap perubahan lahan yang terjadi sedangkan responden 1 dan 4 berpendapat bahwa aksesibilitas merupakan salah satu penyebab terjadinya perubahan lahan karena akses yang baik dapat menarik minat investor maupun masyarakat untuk membangun permukiman di sekitar akses tersebut. Berdasarkan penjelasan tersebut maka dapat disimpulkan bahwa faktor aksesibilitas berpengaruh terhadap perubahan lahan.

\section{3) Faktor Produktivitas Lahan}

Responden 1,2,3 dan 5 sependapat bahwa produktivitas lahan berpengaruh terhadap perubahan lahan. Produktivitas lahan yang tinggi akan menjadikan lahan yang menguntungkan sehingga pemilik lahan akan mempertahankan lahan nya, begitupun sebaliknya, jika produktivitas lahan rendah maka akan membuat pemilik lahan menjual lahannya sehingga terjadi perubahan lahan. Sedangkan menurut pendapat responden 4 bahwa produktivitas lahan bukan faktor yang berpengaruh terhadap perubahan lahan. Produktivitas lahan bukan alasan utama terjadinya perubahan lahan karena harga lahan yang tinggi dan tersedianya aksesibilitas yang baik lebih mempengaruhi terjadinya perubahan lahan. Berdasarkan penjelasan tersebut maka dapat disimpulkan bahwa faktor produktivitas lahan belum tentu berpengaruh terhadap perubahan lahan.

\section{4) Faktor Ketersediaan Sarana dan Prasarana}

Responden 2,3 dan 5 sependapat bahwa faktor ketersediaan sarana prasana berpengaruh terhadap perubahan lahan. Ketersediaan sarana prasarana dinilai mampu membuat masyarakat ataupun investor tertarik untuk membangun permukiman di sekitar kawasan tersebut. Hal ini didasari karena kelengkapan sarana dan prasarana ini mempu mengakomodasi kebutuhan akan suatu kawasan permukiman. Sedangkan pendapat responden 1 dan 4 bahwa faktor sarana dan prasarana bukan faktor yang berpengaruh terhadap perubahan lahan karena faktor aksesbilitas dan harga lahan yang menjadi faktor perubahan lahan. Berdasarkan penjelasan tersebut maka dapat disimpulkan bahwa faktor ketersediaan sarana dan prasarana belum tentu berpengaruh terhadap perubahan lahan.

\section{5) Faktor Kebijakan}

Kelima responden sependapat bahwa faktor kebijakan berpengaruh terhadap perubahan lahan. Menurut responden, suatu kebijakan dapat menentukan arah pembangunan sehingga kebijakan akan selalu menjadi salah satu faktor yang mempengaruhi perubahan lahan yang terjadi. Berdasarkan penjelasan tersebut maka dapat disimpulkan 
bahwa faktor kebijakan berpengaruh terhadap perubahan lahan .

\section{6) Kebutuhan Penduduk Terhadap Lahan}

Kelima responden sependapat bahwa faktor kebutuhan penduduk terhadap lahan berpengaruh terhadap perubahan lahan. Bertambahnya jumlah penduduk sedangkan lahan yang ada tidak bertambah membuat kebutuhan akan permukiman sebagai tempat tinggal sangat dibutuhkan, hal ini menyebabkan terjadinya perubahan lahan. Berdasarkan penjelasan tersebut maka dapat disimpulkan bahwa faktor kebutuhan penduduk terhadap lahan berpengaruh terhadap perubahan lahan.

Berdasarkan penjelasan sebelumnya, masih terdapat beberapa responden yang menyatakan ketidaksetujuan atas fakto-faktor yang ada di masing-masing jenis perubahannya. Tetapi dalam iterasi tahap 1, responden berpendapat bahwa faktor yang diberikan sudah mencukupi sehingga tidak perlu penambahan faktor. Untuk mendapatkan jawaban atas berpengaruh atau tidaknya faktor dalam masing-masing jenis perubahan lahan dilakukan wawancara Delphi tahap II kepada seluruh responden dengan menanyakan beberapa faktor diatas. Untuk lebih jelasnya dapat dilihat pada Lampiran. Berikut

Tabel 6.

Tabel Analisis Delphi Tahap 2

\begin{tabular}{|c|c|c|c|c|c|c|}
\hline & Faktor & $\mathbf{R 1}$ & $\mathbf{R} 2$ & R3 & R4 & R5 \\
\hline & Lahan( NJOP ) & B & B & B & B & B \\
\hline & ktivitas Lahan & B & B & B & B & B \\
\hline $\mathrm{Ke}$ & ediaan Sarana dan Prasarana & TB & ТВ & TB & TB & TB \\
\hline \multicolumn{7}{|c|}{ eterangan: } \\
\hline B & : Berpengaruh & & & & & \\
\hline TB & : Tidak Berpengaruh & & & & & \\
\hline $\mathrm{R} 1$ & : Bappeda Kab Sidoarjo & & & & & \\
\hline $\mathrm{R} 2$ & : PUPR Kab Sidoarjo & & & & & \\
\hline R3 & : Direktur PT.SIPOA & & & & & \\
\hline R4 & : Pakar Akademisi & & & & & \\
\hline R5 & : Tokoh Masyarakat & & & & & \\
\hline
\end{tabular}

7) Faktor Harga Lahan ( NJOP)

Dalam iterasi ke II, kelima responden sependapat bahwa faktor harga lahan ( NJOP ) berpengaruh terhadap perubahan lahan. Responden 4 yang pada awalnya menyatakan tidak berpengaruh telah menyatakan berpengaruh pada wawancara Delphi tahap II dengan alasan Harga Lahan ( NJOP ) selalu diikuti dengan kondisi eksisting namun tetap mempengaruhi perubahan lahan.

Sementara responden 1,2,3 dan 5 menyatakan pendapat yang sama seperti yang telah diungkapkan pada iterasi tahap I. Berdasarkan penjelasan tersebut maka selanjutnya dapat disimpulkan bahwa faktor harga lahan ( NJOP ) berpengaruh terhadap perubahan lahan.

8) Faktor Produktivitas Lahan

Dalam iterasi ke II, kelima responden sependapat bahwa faktor produktivitas lahan berpengaruh terhadap perubahan lahan. Responden 4 yang pada awalnya menyatakan tidak berpengaruh telah menyatakan berpengaruh pada wawancara Delphi tahap II dengan alasan produktivitas lahan bukan alasan utama terjadinya perubahan lahan tetapi produktivitas lahan tetap berpengaruh terhadap perubahan lahan karena produktivitas lahan yang tinggi dapat menguntungkan bagi pemilik lahan tersebut.

Sementara responden 1, 2, 3 dan 5 menyatakan pendapat yang sama seperti yang telah diungkapkan pada iterasi tahap I. Berdasarkan penjelasan tersebut maka selanjutnya dapat disimpulkan bahwa faktor produktivitas lahan berpengaruh terhadap perubahan lahan.

\section{9) Faktor Ketersediaan Sarana dan Prasarana}

Dalam iterasi ke II, kelima responden sependapat bahwa faktor ketersediaan sarana prasarana tidak berpengaruh terhadap perubahan lahan. Tiga responden yang pada awalnya menyatakan berpengaruh (responden 2, 3 dan 5 ) telah menyatakan tidak berpengaruh pada wawancara Delphi tahap II dengan alasan ketersediaan sarana prasarana yang ada di sekitar kawasan belum memadai sehingga tidak berpengaruh terhadap perubahan lahan di sekitar kawasan.

Sementara responden 4 dan 5 menyatakan pendapat yang sama seperti yang telah diungkapkan pada iterasi tahap I. Berdasarkan penjelasan tersebut maka selanjutnya dapat disimpulkan bahwa faktor ketersediaan sarana prasarana tidak berpengaruh terhadap perubahan lahan.

\section{Perumusan Faktor - Faktor Perubahan Penggunaan Lahan Akibat Pembangunan Jalan Tol Waru - Juanda di Kelurahan Tambakoso}

Identifikasi Karakteristik Perubahan Penggunaan Lahan dilakukan melalui deskriptif tdidapatkan tabel sebaran dan luas perubahan penggunaan lahan Sesudah Pembangunan Jalan Tol Waru - Juanda di Kelurahan Tambakoso sebagai berikut :

Tabel 7.

Perubahan Penggunaan Lahan Tahun 2004 - 2009

\begin{tabular}{lll}
\hline \hline Penggunaan Lahan & Menjadi & Luas \\
\hline Tambak & Perdagangan dan Jasa & 0,02 \\
& Permukiman & 2,02 \\
& Fasilitas Umum & 0,00086 \\
\hline Ladang & RTH & 16,02 \\
& Permukiman & 0,004 \\
\hline \hline
\end{tabular}

Tabel 8.

Perubahan Penggunaan Lahan Tahun 2009 - 2017

\begin{tabular}{lll}
\hline \multicolumn{1}{c}{ Penggunaan Lahan } & \multicolumn{1}{c}{ Menjadi } & \multicolumn{1}{c}{ Luas } \\
\hline Perumahan & Perdagangan dan Jasa & 0,015 \\
& Fasilitas Umum & 0,05 \\
\hline Tambak & Industri & 2,31 \\
& Permukiman & 11,04 \\
& Perdagangan dan Jasa & 0,36 \\
& Fasilitas Umum & 1,06 \\
\hline Ladang & Industri & 3,61 \\
& Permukiman & 2,34 \\
& Perdagangan dan Jasa & 0,03 \\
& RTH & 17,40 \\
\hline \hline
\end{tabular}

Berdasarkan perubahan yang terjadi maka dilanjutkan utuk merumuskan faktor - faktor penyebab perubahan penggunaan lahan yang dilakukan melalui analisis Delphi dalam 2 tahap. Hasil analisis delphi yang dilakukan dalam 2 tahap, didapatkan beberapa faktor yang telah disepakati (konsensus) oleh responden penelitian sebagai faktor penyebab perubahan penggunaan lahan akibat pembangunan jalan tol Waru - Juanda. Faktor-faktor tersebut adalah:

Faktor - aktor yang berpengaruh terhadap perubahan penggunaan lahan akibat pembangunan jalan tol Waru Juanda periode 2004 - 2009 adalah sebagai berikut :

1. Harga lahan ( NJOP )

2. Aksesbilitas

3. Kebijakan

4. Kebutuhan penduduk terhadap lahan

Faktor yang berpengaruh terhadap perubahan lahan sebelum pembangunan jalan tol Waru - Juanda periode 2004 
- 2009 adalah faktor harga lahan, aksesibilitas, kebijakan, dan faktor kebutuhan penduduk terhadap lahan. Sedangkan faktor yang tidak berpengaruh adalah faktor produktivitas lahan dan faktor ketersediaan sarana dan prasarana. Produktivitas lahan bukan alasan utama terjadinya perubahan lahan, produktivitas lahan yang tinggi maupun rendah bukanlah penyebab dari perubahan lahan. Ketersediaan sarana prasarana yang ada di sekitar kawasan sudah mencukupi kebutuhan penduduk atau kebutuhan permukiman sehingga ketersediaan sarana prasarana bukanlah pengaruh dari perubahan lahan.

Faktor - faktor yang berpengaruh terhadap perubahan penggunaan lahan akibat pembangunan jalan tol Waru Juanda periode 2009 - 2017 adalah sebagai berikut :

1. Harga lahan ( NJOP)

2. Aksesbilitas

3. Produktivitas lahan

4. Kebijakan

5. Kebutuhan penduduk terhadap lahan

Faktor yang berpengaruh terhadap perubahan lahan akibat pembangunan jalan tol Waru - Juanda periode 2009 - 2017 adalah faktor harga lahan, aksesibilitas, produktivitas lahan, kebijakan, dan faktor kebutuhan penduduk terhadap lahan. Sedangkan faktor yang tidak berpengaruh adalah faktor ketersediaan sarana dan prasarana.Akibat adanya pembangunan jalan tol aksesbilitas di Kelurahan Tambakoso membaik sehingga menimbulkan daya tarik investor, investor melihat harga lahan di kelurahan tambakoso akan semakin tinggi dan produktivitas lahan juga baik sehingga terjadi perubahan penggunaan lahan di kawasan studi.

\section{KESIMPULAN}

Berdasarkan hasil analisa dan pembahasan yang telah dipaparkan, maka didapatkan kesimpulan dari sasaran satu dan dua. Identifikasi Karakteristik Perubahan Penggunaan Lahan dilakukan melalui deskriptif dengan bantuan analisis overlay pada sistem informasi geografis didapatkan Perubahan Pemanfaatan Lahan Sebelum Pembangunan Jalan Tol Waru - Juanda Tahun Tahun 2004 - 2009 didapatkan perubahan pemanfaatan lahan yang paling dominan dari Ladang menjadi RTH seluas 16,02 ha.

Perubahan Pemanfaatan Lahan Akibat Pembangunan Jalan Tol Waru - Juanda Tahun 2009 - 2017 didapatkan perubahan pemanfaatan lahan yang paling dominan dari Ladang menjadi RTH seluas 17,40 ha dan Tambak menjadi permukiman sebesar 11,04 ha.

Faktor - Faktor yang berpengaruh terhadap perubahan penggunaan lahan akibat pembangunan jalan tol Waru Juanda periode 2004 - 2009 adalah sebagai berikut :

1. Harga lahan ( NJOP )

2. Aksesbilitas

3. Kebijakan

4. Kebutuhan penduduk terhadap lahan

Berdasarkan Perubahan penggunaan lahan akibat pembangunan jalan tol Waru - Juanda di Kelurahan Tambakoso periode 2009 - 2017 dipengaruhi oleh faktor faktor berdasarkan variabel sebagai berikut :

1. Harga lahan ( NJOP)

2. Aksesbilitas

3. Produktivitas lahan

4. Kebijakan

5. Kebutuhan penduduk terhadap lahan

\section{DAFTAR PUSTAKA}

[1] H. S. Yunus, Dinamika wilayah peri-urban: determinan masa depan kota. Yogyakarta: Pustaka Pelajar, 2008.

[2] BAPPEDA, "Laporan penyusunan RDTR Kecamatan Waru Tahun 2013-2033,” Sidoarjo, 2017. 